\title{
PERSONNEL MARKETING AS A STIMULANT FOR CREATING A NEW COMPANY IDENTITY
}

\author{
Joanna Żarnik-Żuławska
}

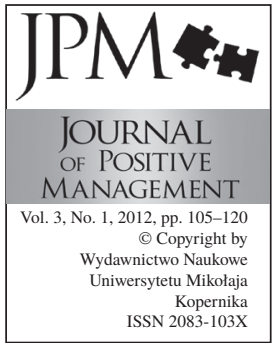

Berendsen Textile Service Sp. z o.o. and

Nicolaus Copernicus University, Toruń, Poland,

e-mail: j.zarnik@interia.pl

\begin{abstract}
The number of companies in the service sector has been growing constantly in the last several years. The appropriate use of staff and professional customer service by employees is possible if the company meets the expectations of employees. Companies pay more attention to the development of such an internal environment that fosters employee satisfaction. This forms a new dimension of the identity of the company, in which ethical norms and values play a crucial role. This paper describes the selected concepts of identity of the organization as the foundation of the creation of the corporate image. The article defines the concepts: personnel marketing, company identity, image of the organization, and explains the relationships between these concepts. The author has tried to find relationship between the Corporate Behaviour and the level of staff satisfaction (new employees) and staff turnover.
\end{abstract}

Keywords: personnel marketing, company identity, image of the organization, corporate behaviour, organizational culture, staff turnover.

Paper type: Conceptual paper

\section{Introduction}

Rapid economic growth, based on knowledge and science, forces companies to manage their intellectual capabilities in a clever and effective way. Human resources are the most important resources for every company. They invent and use technology, manage and multiply the company's assets and are responsible for the value of the company's reputation and trademark. The company's existence and profits depend on employees' behaviour, their way of thinking and way of acting. Without a qualified and motivated team the organization will act in an inappropriate way or will face difficulties reaching their strategic goals.

The biggest achievements in the study of s human capital were made in the last decade of the 20th century. The main effort of researchers was visible in marketing based business orientation, which was developed in those times. That concept emphasizes the importance of business culture and the usage of marketing 
PERSONNEL MARKETING

Joanna Żarnik-Żuławska to motivate the organization to be able to meet the client needs (Mroziewicz, 2008).

The growth of the share of services sector in the growth of GDP, both in the USA and the EU, and the growing number of companies operating in the field of services, resulted in higher interest in the employee abilities such as: communicative skills and the ability to build relationships. Modern companies are more and more dependent on the qualifications, skills and commitment of their employees. On the other hand, employees show a greater ability to change employers, an opportunity to take new experience and skills. It results in the higher rotation factor and the need to create systems securing a long term cooperation between the company and its employees (Mruk et al., 2005).

The proper usage of the company employees' abilities, aimed at best customer service, requires a verification of the standards of human resources management systems. This paper describes the company identity fields like: behaviour, values, organizational culture and communication as a key factor in building the company image. The philosophy of human resources management, from the marketing point of view, is shown on background of current market changes, including new customers' expectations for all kinds of businesses.

The goal of the article is to clarify the meaning of: personnel marketing, company identity, image of the organization, and explains the relationship between these concepts. This paper also tries to find the relationship between the implementation of Corporate Behaviour and the level of staff satisfaction and staff turnover. The subject was analysed using the results of empirical research. The study has been conducted by a questionnaire. The interpretation of the data was the inductive-deductive method. Exploring the topic concludes that personnel marketing is not only an alternative development of the concept of human resource management. Its implementation to the company changes the behaviour within the organization and helps to build a competitive advantage in the market.

\section{The essence of personnel marketing}

Technological and technical progress causes that the effectiveness of a company relies mainly on the effectiveness and creativity of its employees. Every clever idea created by a single employee, applied in an organization, makes it more innovative and in the long run, more competitive (Gruszecki, 2002). Proper abilities, attitudes, knowledge, behaviour and skills of the employees in conjunction with their motivation to take on their duties and responsibilities are the key factors for a company's effectiveness.

The number of companies operating in the service sector is constantly growing. In this type of business, the main link between the company and its customers are the company's employees. Personnel responsible for contacts between both sides have to know how to fulfil their duties, but they should also 
do their work with passion and satisfaction, because these are the key factors for a satisfying level of a service (Otto, 2001).

Personnel marketing is aimed at creating a constant ability of the employee to behave in such a way towards customers that would keep the competitiveness on a high level (Altkorn 2002). Personnel marketing is also a sign of an alternative attitude to human resources management and traditional marketing. Sometimes it possible to find a term called "internal relationship marketing" (Otto, 2001). This concept is linked with an adaptation of techniques used usually in external surrounding of a company, but in personal marketing it is used in internal environment. According to Natalia Szozda internal marketing is based on attracting, training and motivating staff in contact with customers to create a team capable of meeting the needs of buyers. (Szozda, 2011). Usage of a personnel marketing makes employees satisfied with their jobs and their employer and also their workplace and work conditions comfortable and meeting their expectations. It should result in higher satisfaction of customers, building and keeping strong business relationships with them and improving the company's effectiveness (it is shown in Figures 1 and 2). In fact, personnel marketing means that high standard of the internal client (employee) and external customer service should be promoted. Company which uses personnel marketing is open to the needs and expectations of the employees, because fulfilling those needs, creates the ability to transfer this satisfaction to customers and as the final effect, the positive external image of company.

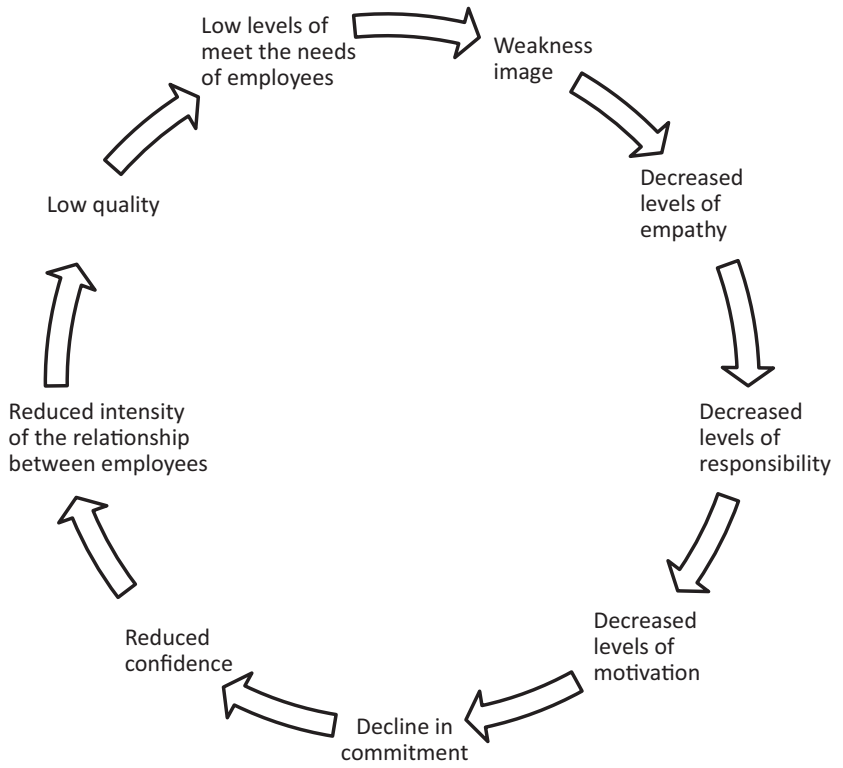

Figure 1. The vicious circle of low-quality relationships Source: Wiścicka (2010:299). 
PERSONNEL

MARKETING

Joanna Żarnik-Żuławska

Figure 2.

The relationship between employee satisfaction and customer retention

Source: Otto (2001:193).

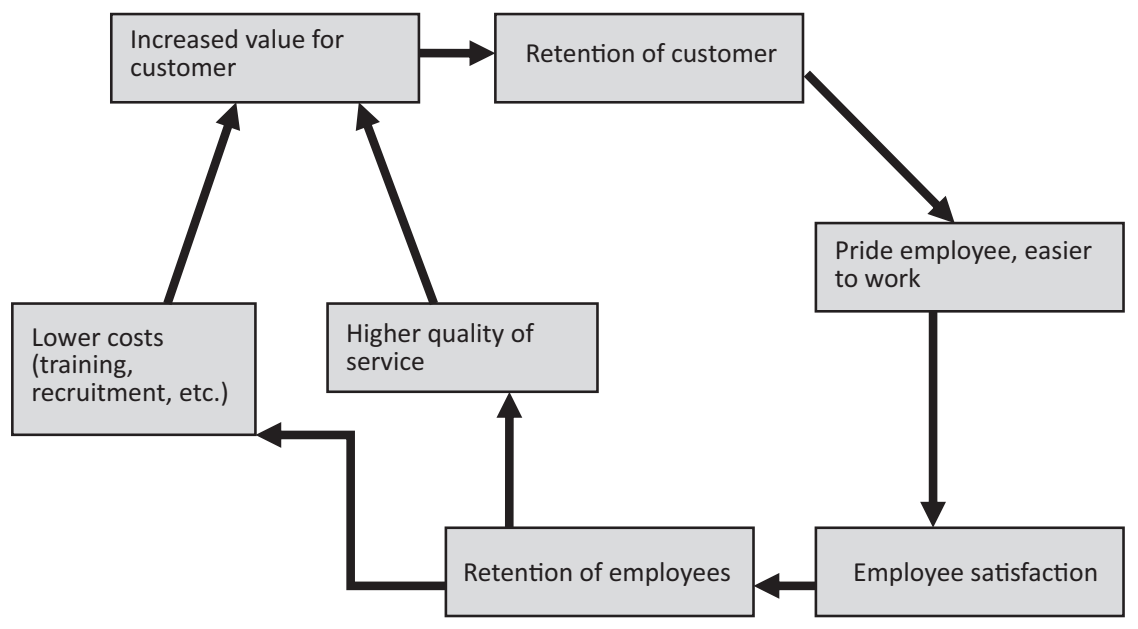

\section{Identity - inseparable element of a company}

The identity includes the main and the outstanding attributes concerning a given organization such as behaviour, values, organizational culture, and communication (Konecki, 2002).

The organization is recognized in comparison with other internal and external expositions of its attributes. Professor Konecki points out that we are dealing with an identity perceived by the members of the organization (as this relates to the characteristics of organizations that are considered by their members as a major, permanent, and distinguishing among others).

On the other hand there is a "construed external image", which relates to the characteristics of the organization deemed by the participants in the external environment as a major, sustained, distinguished by perceptions and opinions of members of the organization. So an identity is expressed through the opinions of its members about their company and market opinions about the organization, built on the basis of the perception of members of the organization.

In summary, the visible demonstrations of the opinions and perceptions of members of the organization are subjected to assessment by the external environment. On their basis, the recipient creates the impression of the company, a subjective image, or a reflection of the company. Such an approach blurs the differences between the concept of "the image of the organization" and "the identity of the company." Despite the existing interdependencies between these concepts, a fundamental difference lies in the fact that the image is something external to the company, which it can only seek to influence. Identity is an integral part of the organization, which it can fully decide upon (Zarębska, 2008). 
The identity of the company understood as intangible asset, or as an companies, is usually considered in three aspects: Corporate Design (logos, uniforms, etc.), Corporate Communication (public relations, information, advertising), Corporate Behaviour (standards, values, behaviour). In the following part of this paper, attention is drawn to the aspect of corporate behaviour as a base to build the image of the employer. The identity of the companies described below is understood as a set of values and principles shared by employees and managers, so that it becomes an expression of culture. Identity includes the features that people consider to be crucial, important and lasting in describing the operation of their business (Głuszek, 2004).

\section{Relationship between the identity, personnel marketing and image of a company}

The image is the representation of the company in the mind of other people, who come into contact with it directly (e.g. employees, customers) or indirectly (the market and its participants) (Cenker, 2000).

A proper image gives the company a competitive advantage in today's markets. The intensive development of knowledge-based economy forces companies to skilfully and effectively manage reputation. The image, meaning the opinion about the organization is the information aimed for investors, employees, customers and the environment, and in this way the company gains real, economic value. This is confirmed, inter alia, by Johathan Law, Pam Cohen Kalafut in the book "Intangible goodwill hidden source of competitive advantage" (Low and Cohen Kalafut, 2004).

While building its image, company should pay attention to several aspects of the identity of the business. These include logo, public relations, advertising, standards, values, etc. from which organizational culture and shaping relations through decision-making strategy, actions and reaction to employees' needs plays a crucial role in personnel marketing. The essence of personnel marketing is shaping and consolidating the company's image as an attractive employer. Actions taken by the Board and managerial staff come from the nature (identity) of the company, which means that identity is the backbone of the company's image as an employer in the market. In order to communicate their identity to employees and job candidates, the company has to make the so-called self-presentation of its policies, actions, and plans. These presentations can be interpreted in different ways, thus creating a more or less favourable image of the company. A good example of such self-presentation is the McDonald's advertising campaign in 2009, which was an attempt to build the picture of McDonald's as an employer offering a development system for new employees within the organization through vertical promotion in the company's organizational structure [1]. 
PERSONNEL MARKETING

Joanna Żarnik-Żuławska
When one decides for this type of self-presentation in order to communicate their identity, one should consider that the company's image is affected by at least two components: what people, customers, competition thinks and says about the organization and what employees say about the organization [Głuszek, 2004, p. 139-143]. Thus, companies in their presentations should be reliable, accurate and consistent with the internal situation. In the consumer world, the apparent loss of trust means the loss of the entire network of potential customers.

Consistency of the identity of the business with self-presentation which has been made will result in building the desired image of the company on the market. Building a good image requires not only the marketing activities, but, above all, maintaining principles and values in relationships with employees. As a result, satisfied staff will contribute to building a positive opinion of the company on the market, and a greater involvement of the employees will help to increase productivity and efficiency in external customer service (Głuszek, 2004).

Creating a positive image of the employer is one of the main objectives of personnel marketing. The identity of the company, built and developed on the basis of healthy organizational culture, ethical principles, values, and positive relationships with employees helps the company to attract real talent (good values attract good people), facilitates the integration of employees around common goals, even in the presence of differences, and builds satisfaction among workers. Thus, the identity of businesses is important for the success of the objectives of personnel marketing. Achieving these objectives means that some companies are rated much higher than the competition although they have similar range of products and services (Kotler, 2010).

\section{The importance of ethics in personnel marketing}

Over the years, marketing has undergone evolution including three stages, which are called marketing, 1.0, 2.0, 3.0. These changes also had an impact on the theory of personnel marketing. Marketing 1.0 is from industrial times. During this period products were mass produced and assigned to the broad market. Only standardization counted in order to reduce the production cost and price of the product. Marketing 2.0 was born in the era of information. Well-informed consumers could compare a few offers and due to the different tastes they assessed the value of each product differently. Marketing tasks became more difficult. There rose a need for skilful differentiation according to the needs of each audience. Nowadays, we are witnessing Marketing 3.0. Customers are trying to find the products and services that address their individual concerns and worries. As individual units, they are not able to improve social or economic background. Also, customers are aware that being part of a huge crowd of consumers, as a group, they are given the possibility to improve the world, thus raising their self-esteem. Good example of Marketing 3.0 is the existence of mineral water 
ads, in which there is information that part of the proceeds from the purchase of advertisement "My strong tree" from 2011 years, recipient of the product gets the opportunity to participate in the global share of tree planting action [2].

In this way the company shapes its image as being responsible for the environment. Hoop Cola drink ad- Who are you? from April 2011 refers to the tolerance and acceptance of cultural differences and openness to racial differences [3].

Today, people are looking for companies which, through fulfilling their stated mission, vision and values satisfy the customer's desire for social justice and their economic and environmental needs (eco products). 3.0 concept creates traditional marketing, together with personnel marketing to the level of human values, aspirations and spirit (Kotler, 2010).

Creation of the company worthy of admiration and credible in the eyes of external customers requires the company to build trust among internal customers, which means employees. In this way, the employees' positive attitude and enthusiasm will affect the consumer and embed in them the sense of social justice and ethics in business. Reputation Quotient research, conducted by Harris Inteactive, published in 2008, shows that half of Americans recognize that companies in addition to making a profit, also have obligations towards their employees and customers. Nearly half of them believe that companies should also help in solving global problems such as poverty, hunger and diseases (DobiegałaKorona and Doligalski, 2010).

In other countries, the percentage of ethical consumers is sometimes even higher. According to the Danish analysis, this category of consumers is in this country more than half of buyers (Dobiegała-Korona and Doligalski, 2010). The so-called group of ethical consumers consists of generally better educated and more aware people that often play an important role in shaping public opinion. For those consumers the evaluation criteria for selection of a product or service factors are: compliance with the code by the employer, principle of equality and fair play. When making purchase choices, this group welcomes the companies with higher ethical standards.

Not surprisingly, more and more attention is paid to clear definition and communication of the mission, goals and values of the company. In this way, companies contribute to building a new dimension of organizational culture and identity, in the long term to meet the challenges of growing corporate social responsibility. Vision and values of Johnson \& Son is an example. For Johnson \& Son vision, understood as the reason for the company's existence, amounts to "being a world leader in providing innovative solutions that meet human needs through the principle of sustainable development." And the value is defined as mandatory standards and behaviours tending to create economic value, healthy 
PERSONNEL

MARKETING

Joanna Żarnik-Żuławska environment, and promote social development, the belief that the fundamental strength of the company is associated with people working in it. Additionally, the company puts much effort in promoting family values among employees. Working at Johnson \& Son means keeping a balanced life, in which there is room for both work and family (Kotler, 2010).

Modern businesses are challenged to convince both consumers and workers to their values. Consumers can quickly identify inauthentic brand. Employees do it a lot easier, because they see everything from the inside of the organization. Therefore, the goals of primary and secondary personnel marketing strategy begin with shaping the identity of the business. The company, which acknowledges a good value in the market, has an advantage in the fight for talented employees. The effectiveness of the organization is higher if workers have an established set of principles and values in their environment. Moreover, the company, which has healthy principles, values and standards, and ensures free flow of information, has a greater capacity to cope with conflicts and intercultural differences, which is particularly important in large, international enterprises.

To sum up, assessment of the value of goods and services in individual companies depends increasingly on the characteristics of entrepreneurs themselves, their rules, norms, organizational culture and relationships with employees. Currently, the dominating trends include a growth of expectations for the role of enterprises and a greater need to track business activities resulting from improved access to information. This, in turn, increases the importance of the corporate image, and the reliable sources of information are the employees themselves. Organizations pay more attention to the development of an internal environment that fosters employee satisfaction, and thus form a new dimension to the identity of the company, which plays a crucial role in the ethical norms and values. The aim is to build the image of a desired employer and a socially responsible entrepreneur. Good reputation enhances the benefits and reduces costs, while increasing the customer value and competitive advantage in the market.

\section{Organization identity areas and their influence on personnel marketing goal realization}

Personnel marketing is an expression of development of alternative approaches to human resources management in organizations and is a result of the emerging need to meet the standards of the competitive modern world. At the basis of human resources management underlies the striving to achieve competitiveness on the market thanks to proper impact on people employed in a given organization. Therefore, people are treated as one of the company's assets which, through the manifestation of activity contribute to the implementation of the strategic objectives of the company (Armstrong, 2007; Bańka, 1998). 
In the concept of personnel marketing the company and its interior is treated in market terms. Participants of this market are internal buyers (employees), external buyers (potential employees) and the market environment (Zbigień-Maciąg, 1996). Personnel marketing is based on creating and maintaining emotional bonds allowing the feeling of loyalty and satisfaction among workers, which translates into customer satisfaction and builds a positive image on the market. Thus, the primary goal of personnel marketing comes down to identifying the needs of current and prospective employees, and fulfilling them in the best possible way, by creating a supportive working environment.

Personnel marketing in comparison to the concept of human resource management is characterized by the following items. First of all, emotional ties are stronger than economic ties. Secondly, perceiving members of the organization as internal customers (buyers). Thirdly, personnel marketing has a much wider range of influence. Actions taken under the theory of human resource management are addressed solely to the employees of the organization. The concept of personnel marketing is that actions taken by the company are addressed not only to the present but also to potential employees, as well as buyers of products and services offered by the company. In personnel marketing the internal client (employee) is in the spotlight. It helps to increase the importance of internal communication system, the incentive system or the system of internal recruitment (through which the company confirms its loyalty to employees), and consequently the company's organizational identity. "The success of personnel marketing programs depends on many factors; in particular attention should be paid to build an effective internal communication, creating an organizational culture based on leadership, and other values such as dissemination, involvement, cooperation, common shared responsibility, concern for the customer" (Otto, 2001). HR marketing programs offer real opportunity to improve or develop new quality of work and deepen the involvement of employees in the company's strategic objectives.

Given the fact that personnel marketing, associates with creating and maintaining a company's image as an attractive employer, one may assume that organizational culture significantly affects the way of shaping the image of the company. Moreover, it determines the way employees work, the relationship between them and managers, customers and suppliers, and strongly influences the practice of management and other processes in the enterprise (Głuszek, 2004). "Organizational culture is a pattern of values, norms, beliefs, attitudes and assumptions, which need not be formulated, but that shape human behaviour and ways of implementation of tasks. Values refer to what is considered important in the behaviour of people and organizations. Norms are the unwritten rules of behaviour" (Armstrong, 2004). According to Elliot Jaguesa culture concept covers a wide range of behaviour, professional competence, knowledge, attitudes towards
PERSONNEL MARKETING

Joanna Żarnik-Żuławska 
PERSONNEL

MARKETING

Joanna Żarnik-Żuławska discipline and punishment, customs and habits in the behaviour of managers, the objectives of the company, its mode of action, methods of pay, the values associated with different types of tasks, belief in a democratic way of life and joint consultation (Lundy and Cowling, 2000).

Building a corporate image as an employer begins at the moment when one chooses how to act and decide within the organization, which later shapes the principles and goodwill of the company. Trust is a fundamental value in building good reputation. For employees the fundamental question is whether their employer is reliable and trustworthy. Trust is manifested, among others, in the sense of safety in the workplace and in the treatment of workers by the managerial staff of the company. Companies often have a false sense that their customers are in the first place. Meanwhile, most workers do not put customers first, and certainly does not do it just because that is what the employer expects from them. Only people with the feeling that their needs are put first, can honestly share with others and draw satisfaction from it (Rosenbluth and Peters, 2009).

Another value which shapes the identity of the company and has impact on employee and customer satisfaction is teamwork. Changes in business and personal approach to customer require workers to develop team skills in order to reach creative and innovative solutions. Moreover, teamwork contributes to greater integration of workers and better flow of information and knowledge. "Teamwork contributes to the fact that the company becomes a learning organization, one in which a continuous flow of knowledge is the basis for improvements and changes to raise the competitiveness of the company" (Mruk and Pilaczyk, 2005).

Building a good reputation about the company among employees requires the development and implementation of incentives taking into account material and immaterial instruments, as well as a skilful application of relevant principles in motivating employees, such as individualization and concreteness from the executives. Effective motivation comes down to paying attention both to the mission, strategy and objectives of the company and the needs and expectations of employees. Failure to consider both of these conditions is the cause of poor performance and failure (Kasiewicz and Możaryna, 2004). "The growing role and importance of the employee in the enterprise and the need to treat him/her in a more comprehensive and subjective way, made the term order obsolete, and in its place, nowadays, along with motivating, there appeared the term leadership" (Haffer and Sudoł, 1999).

Given the fact that it is the leaders who decide the direction and dynamics of enterprise development, the most important element of leadership is to have an inspiring vision of development and communication skills of its employees in such a way that these employees would be involved in its implementation. John Yokoyama noted it and is now the owner of Pike Place Fish Stall in Seattle, which has produced such a remarkable corporate culture at his company, that it has 
encouraged the leaders of organizations such as Panasonic, Ford or Marriot to implement his philosophy of work. "The employee does not become a co-owner of a vision, if the employer simply tells him to sign under it. Employee forced to accept top-down mission is limited to create the appearance of its application. The result is different when the employee genuinely shares the values and mission of the organization. We at Pike Place Fish devote much time to discussions, during which we explore our vision. We do not ask employees to read about this vision. We haven't written it on the paper and hung on the wall. Our vision is with us every day, in the daily duties" (Yokoyama, 2007).

The ability to communicate and integrate employees around the vision and mission of the organization is an important attribute of leadership that makes it easier to focus on selected strategic objectives of the company. Employees become interested in not only the objectives and tasks, but also the rationale for their implementation. This indicates significant factors in effective leadership, which are communication skills and openness to differences of opinion. Communication is not limited to motivating and shaping values. "The leadersas Warren Bennis and Bunt Nanus write- express and define the unspoken or implied content, bring ideas, metaphors and examples. In this way, they instil or undermine the knowledge possessed by employees. In short, a key element of leadership is to influence the members of the organization and develop their knowledge (...). Communication is, or at least should be, used only to relevant content to workers. In case of any community, large or small, it is the only way to union workers under the banner of the overriding objectives of the organization" (Phillips, 2009).

Persuasion rather than imposition and the use of position certainly require communication skills. Implementation of open-door policy, freedom of communication and the principles of tolerance for different opinions means listening to other people, even if this requires changing one's mind. The introduction of the freedom to propose new solutions and taking creative actions, and the inclusion of workers in the decision-making process (participation) has a beneficial effect on the company and its image in the eyes of employees. Not surprisingly, an increasing number of employers undertake the challenge of building the partnership-style management. A bigger interest in the partner model is shown e.g. in personnel policies of the company Bre Bank S.A. The employee evaluation system introduced in that organization is based on a system of management by objectives. It requires the establishment of individual goals and objectives for each employee at the beginning, but with some room for modification while the fulfilment of these goals is in progress. Development and setting goals is based on a partnership basis. It gives an opportunity for active participation of employees in the process of formulating goals (Romanowska and Trocki, 2002).
PERSONNEL MARKETING

Joanna Żarnik-Żuławska 
PERSONNEL MARKETING

Joanna Żarnik-Żuławska
In conclusion, treating employees as internal clients creates a work environment which fosters leadership, sharing information, nurturing the development and involvement in the decision-making process, allowing the formation of emotional bonds between employee and employer. This affects the creation of the staff's positive image on the market and gaining greater efficiency in the scale of economic organization.

\section{Practical experience of international companies in the field of relationship marketing}

The selection process and implementation of new employees to the organization affects their involvement and shaping the identity of the company.

Areas of action described below affect the company's image in the opinion of potential and new employees.

Table 1 presents the practices undertaken in an international company providing services in the textile industry and their relationship to the level of employment costs of the company.

Research have been conducted by author in the period January-September 2011 in five plants in Poland. The study was conducted in two departments: sales and customer service department and concerned two positions: Sales Representative and Customer Service Specialist.

In order to assess personal marketing instruments was carried out survey relating 17 recruitment projects. The study was designed to assess the satisfaction of new employees. The study included an international service company. To collection data used the questionnaire. The author has collected also data on the measures introduced by the company since January 2011, concerning of recruitment process.

Recruitment was carried out 17 projects in the two departments under study. Employment contract has been signed with 16 employees. 12 employees were asked to job satisfaction rate during the probationary period.

The Company introduced three major changes: improved the quality of job advertisements, introduced uniform principles of selection of employees and implemented the standards associated with the introduction of new employees to the company. This resulted in an increase in applications in the system, satisfaction of new employees (what shows Figure 3), decrease in employee turnover (what shows Table 2) and lower costs of staff recruitment. An additional, immeasurable benefit was company's advertising (in job advert added a company logo and photos).

Employees were most satisfied with the level of responsibility and cooperation with supervisors. Human Resources should take steps leading to improved collaboration between departments and within teams. The vast majority of new employees were happy to be working with company. 


\begin{tabular}{|c|c|c|}
\hline ACTION & DESCRIPTION & RESULT \\
\hline $\begin{array}{l}\text { Visual } \\
\text { quality } \\
\text { of job } \\
\text { advertise- } \\
\text { ments }\end{array}$ & $\begin{array}{l}\text { The company has made changes to } \\
\text { the quality of published job adver- } \\
\text { tisements. Changes related to three } \\
\text { elements: } \\
\text { - added photos and company logos for } \\
\text { advertising content, } \\
\text { - notice published in the most widely } \\
\text { read website, } \\
\text { - modified contents of the announce- } \\
\text { ment, added information about the } \\
\text { responsibilities and the additional } \\
\text { components of the remuneration } \\
\text { offered by the company. } \\
\text { - Responsibility for activities related to } \\
\text { the publication of job advertisements } \\
\text { has been shifted from line managers } \\
\text { on HR department }\end{array}$ & $\begin{array}{l}\text { The increase in the average num- } \\
\text { ber of applications received within } \\
\text { the one recruitment project of } 48 \\
\text { applications in the period January- } \\
\text {-December } 2010 \text { to } 133 \text { applications } \\
\text { in January-September } 2011 \\
\text { - Promotion, advertising companies on } \\
\text { the market (in the costs of recruit- } \\
\text { ment) } \\
\text { - Reduction in the average unit price of } \\
\text { the notice of } 32 \% \text { over the previous } \\
\text { year }\end{array}$ \\
\hline $\begin{array}{l}\text { Rules for the } \\
\text { selection of } \\
\text { personnel }\end{array}$ & $\begin{array}{l}\text { - Described and implemented a proce- } \\
\text { dure for describing the rules for the } \\
\text { selection of personnel } \\
\text { - Describe the stages of the recruit- } \\
\text { ment process } \\
\text { - Competence profile of candidates } \\
\text { prepared } \\
\text { - Developed policies and tools to } \\
\text { assess candidates } \\
\text { - Trained regional managers }\end{array}$ & $\begin{array}{l}\text { Building an image of a professional } \\
\text { acting company }\end{array}$ \\
\hline $\begin{array}{l}\text { Rules for the } \\
\text { implementa- } \\
\text { tion of new } \\
\text { employees }\end{array}$ & $\begin{array}{l}\text { Described and implemented a proce- } \\
\text { dure for describing the rules for the } \\
\text { implementation of new employees } \\
\text { - Unified phases of the process of } \\
\text { adaptation } \\
\text { - Accurately describe who and what } \\
\text { information is to give the new em- } \\
\text { ployee } \\
\text { - It was found that each new employee } \\
\text { including starting a managerial posi- } \\
\text { tion or a job in the Sales Department } \\
\text { and Customer Service passes imple- } \\
\text { mentation program that includes: the } \\
\text { transfer of general information about } \\
\text { the company, its mission, vision and } \\
\text { values, detailed employee familiar } \\
\text { with the functioning of departments, } \\
\text { define tasks, responsibilities and } \\
\text { expectations associated with the } \\
\text { work of the position, learning with } \\
\text { colleagues. }\end{array}$ & $\begin{array}{l}\text { - Assessment of employee satisfaction } \\
\text { (see Figure 3) } \\
\text { - Reduce the staff rotation (see Table } \\
\text { 2) } \\
\text { - Reduction of employment costs }\end{array}$ \\
\hline
\end{tabular}


PERSONNEL

MARKETING

Joanna Żarnik-Żuławska

Figure 3.

Satisfaction rating during the trial period

Source: own work

Table 2.

Level of staff turnover (rotation) of new employees

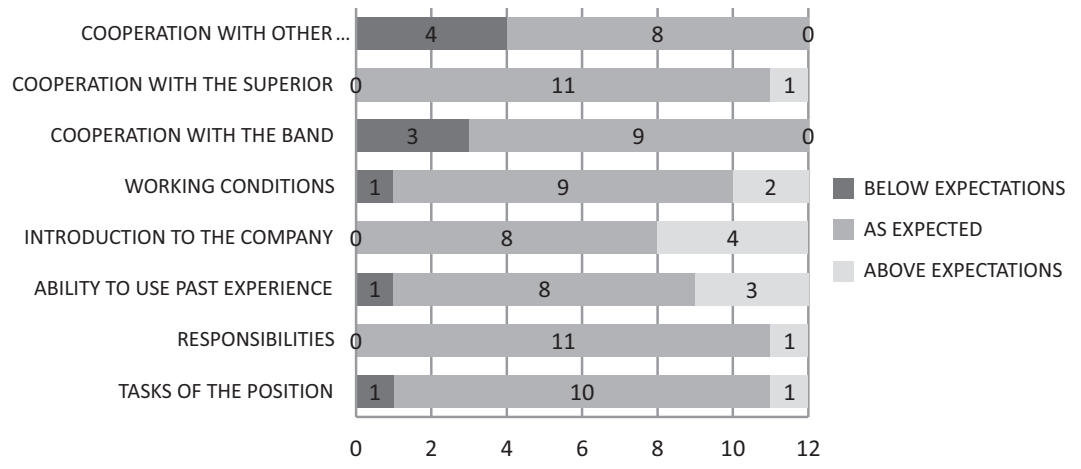

\begin{tabular}{lcc}
\hline TIME & JANUARY - SEPTEMBER & JANUARY - SEPTEMBER \\
DEPARTMENT & 2010 & 2011 \\
\hline Total Company & $11,6 \%$ & $11,2 \%$ \\
\hline Sales Department & $28,6 \%$ & $0 \%$ \\
\hline Customer Service Department & $33,3 \%$ & $25,0 \%$ \\
\hline
\end{tabular}

Obtained a greater number of applications, the company advertised in the market in the costs of recruitment. Information about the vacancy came to a larger number of candidates. Increased probability of selection motivated and highly qualified personnel.

Greater attention has been shown to new employees. Ensured the reliable transfer of information on issues such as mission, vision and values. The recruitment process is a cost item. Their reduction increases the company "s competitiveness in the market.

\section{Conclusion}

The implementation of the strategic objectives of the organization is very difficult, mainly due to the continuous progress and impact of objective market condition. Effective change management involves people, ideas, opportunities, needs, finance, and marketing. The vision, communication, creativity, teamwork and trust are equally important. Companies that want to survive and meet the demands of today's competitive world must change themselves from within. Some of them would prefer to do it through a gradual process of change. Personnel marketing as a manifestation of incremental changes in the approach to managing people in an organization takes into account the validity of the principles such as cooperation, moral values and the culture of the organization, in achieving business objectives. The advantage of emotional bonds over economic ones and 
the awareness of the employees' influence on the reputation of the company are characteristic for the concept of personnel marketing. These changes were accompanied by a simultaneous search for social justice in the business term. It all together brought traditional marketing and personnel marketing with the identity of the company, on the level of not only values and aspirations, but also spirituality. Considering and addressing the needs of internal customers (employees) and external ones (potential employees, customers for the goods and services) is building a positive image of the company as an employer and is a part of the idea of corporate social responsibility. This gives the company more profits and greater competitiveness.

\section{Notes}

[1] Movie from YouTube encouraging to work for McDonalds, watched by 18,5 thousand people available at: http://www.youtube.com/watch?v=TPZSnxzn0VU\&feature=related (accessed 7 May 2011).

[2] Movie from YouTube, commercial movie „My strong tree”, available at: http://www.youtube. com/watch?v=NMeeK2t4ET8\&feature=related (accessed 7 May 2011).

[3] Movie from YouTube, commercial movie „Hoop cola - Who you are?”, available at: http://www. youtube.com/watch?v=By8f9m5uQxk (accessed 7 May 2011).

\section{References}

Altkorn, J. (2002), Kształtowanie nowego wizerunku firmy, Wydawnictwo Akademii Ekonomicznej, Kraków.

Armstrong, M. (2007), Zarzadzanie zasobami ludzkimi, Wydawnictwo Wolters Kluwer Polska, Kraków.

Bańka, W. (1998), Zarzqdzanie personelem w przedsiębiorstwie, Wydawnictwo Adam Marszałek, Toruń.

Cenker, E.M. (2000), Public Relations, Wydawnictwo Wyższej Szkoły Bankowej, Poznań.

Dobiegała-Korona, B., Doligalski, T. (2010), Zarzadzanie wartościq klientów. Pomiar $i$ strategie, Wydawnictwo Poltext, Warszawa.

Głuszek, E. (2004), Zarządzanie zasobami niematerialnymi przedsiębiorstwa, Wydawnictwo Akademii Ekonomicznej, Wrocław.

Gruszecki, T. (2002), Wspótczesne teorie przedsiębiorstw, Wydawnictwo PWN, Warszawa.

Haffer, M., Sudoł, S. (1999), Przedsiębiorstwo wobec wyzwań przyszłości, Wydawnictwo Naukowe Uniwersytetu Mikołaja Kopernika, Toruń.

Kasiewicz, S., Możaryn, H. (2004), Teoria przedsiębiorstw, Wydawnictwo Szkoły Głównej Handlowej, Warszawa.

Konecki, K. (2002), „Odporność na zmianę. Główne czynniki zmiany tożsamości organizacji w polskich przedsiębiorstwach przemysłowych”, in: Konecki, K. (Ed.), Socjologia Gospodarki. Rynek, instytucje, zarzqdzanie, Wydawnictwo Naukowe Wyższej Szkoły Kupieckiej, Łódź, available at: http://qsr.webd.pl/KKonecki/publikacje/publikacja9.html (accessed 6 November 2012).
PERSONNEL MARKETING

Joanna Żarnik-Żuławska 
PERSONNEL MARKETING

Joanna Żarnik-Żuławska
Kotler, P. (2010), Marketing 3.0, Wydawnictwo MT Biznes Sp. z o.o., Warszawa.

Low, J., Kalafut, P.C. (2004), Niematerialna wartość firmy. Ukryte źródta przewagi konkurencyjnej, Wydawnictwo Oficyny Ekonomicznej, Kraków.

Lundy, O., Cowling, A. (2000), Strategiczne zarzadzanie zasobami ludzkimi, Wydawnictwo Oficyny Ekonomicznej, Kraków.

Mroziewicz, M. (2008), Kapitał intelektualny współczesnego przedsiębiorstwa, Wydawnictwo Difin, Warszawa.

Mruk, H., Pilaczyk, B., Szulce, H. (2005), Marketing uwarunkowania i instrumenty, Wydawnictwo Akademii Ekonomicznej, Poznań.

Otto, J. (2001), Marketing relacji. Koncepcja i stosowanie, Wydawnictwo C.H. Beck, Warszawa.

Phillips, D.T. (2009), Abraham Lincoln: skuteczne strategie na trudne czasy, Wydawnictwo Helion, Gliwice.

Romanowska, M., Trocki, M. (2002), Przedsiębiorstwo partnerskie, Wydawnictwo Difin, Warszawa.

Rosenbluth, D., Hal, F., McFerrin, P. (2009), Po drugie klient. Zadowoleni pracownicy gwarancja sukcesu firmy, Wydawnictwo Oficyny Ekonomicznej, Kraków.

Szozda, N. (2011), "Instrumenty marketingu wewnętrznego w firmach usługowych branży IT”, Zeszyty Naukowe Wyższej Szkoty Zarządzania Ochrona Pracy w Katowicach, 1(7), pp. 173-185.

Wiścicka, M. (2010), “Czynniki kształtujące zachowania personelu jednostek samorządu terytorialnego jako wewnetrznego klienta firmy", Zeszyty Naukowe Uniwersytetu Szczecińskiego, No. 15, pp. 293-305.

Yokoyama, J., Michelli, J. (2007), Kiedy ryby lataja. Jak stworzyć energiczne środowisko pracy, Wydawnictwo MT Biznes, Łódź.

Zarębska, A. (2008), Tożsamość organizacyjna przedsiębiorstwa, Wydawnictwo Difin, Warszawa.

Zbigień-Maciąg L. (1996), Marketing personalny, czyli jak zarządzać pracownikami $w$ firmie, Wydawnictwo Business Press, Warszawa. 